Having cut through the epidermal cells, so as to discharge their contents, and thus prevent them from exerting any lateral pressure on the guardian-cells, it was found that when placed in water (which they imbibe), the guardian-cells increased the space between them very perceptibly; but when placed in a solution of sugar (into which they exude a portion of their contents), they closed it completely. By changing from water to a solution of sugar, the same opening might be alternately opened and closed. Another series of experiments on intact leaves showed that this action of the guardian-cells is impeded by the pressure of the epidermal cells, in proportion as they come into contact with the former. This is also shown by the fact, that when this pressure is taken off by emptying the epidermal cells of their contents (which may be done by immersing the latter in a solution of sugar), the guardian-cells always open. As the epidermal cells contain more sap than the guardian-cells, the same result is obtained by letting a leaf wither off. The orifices of intact leaves cut off in the morning were found to be closed; when exposed to the sun for several hours, they opened again, but closed with rapidity when immersed in water,- showing that the power of the guardiancells is increased, in comparison with that of the epidermal cells, by the influence of light and heat, quite independently of the humid state in which they may occur. This, the author thinks, can hardly be explained except by assuming that when the guardian-cells are exposed to the influence of these agents, they form such combinations as are able to induce a powerful endosmosis, and are more or less decomposed when light is withdrawn; for, as is well known, the guardian-cells, like the cells of the parenchyma, contain chlorophyllaceous matter.

Direct comparative measurements show that the projecting part of the guardian-cells, beyond the anterior cavity, contracts but slightly, so that the process is effected chiefly by the change in the form of the boundaries of the true opening.

The guardian-cells expand most in a vertical direction, and thus change their transverse diameter from a circular to an elliptical form, so as to draw in the thinner portion of the lateral surface which lies free in the opening of the stomate. This explains why the opening is not closed when these cells are distended by the water which fills them.-Botanische Zeitung, 1856, No. 40, and Silliman's Journal, March 1857.

Descriptions of new Norwegian Annelides. By M. SARs.

\title{
Family Telethusa.
}

\section{Genus Notomastus, Sars, n. g.}

Lobus capitalis conico-acuminatus. Os subtus ; pharynx exsertilis breviter clavata, papillis obsita. Anterior corporis pars cylindricosubfusiformis, e segmentis duodecim medio sulco in annulos duos divisis, primo absque et cæteris undecim utrinque fasciculis binis setarum eapillarium, mamillis pedalibus earentibus, composita. Posterior corporis pars longior et tenuior, e segmentis constans numerosis 
indivisis, utrinque mamillis pedalibus seu toris et superioribus et inferioribus sine setarum uncinatarum ornatis. Branchiæ nullæ.

Species unica: Notomastus latericeus.

This species resembles an Arenicola, and belongs, like it, to the family Telethusa. Its nearest ally is Dasybranchus of Grube (Fam. der Anneliden). Its colour is a brilliant red on the anterior part of the body, brick-red on the posterior, passing gradually into reddishyellow and yellow. The pedal tubercles are all of a paler red or yellowish-red. Its length is 5-6 inches, and its breadth about $\frac{1}{6}$ th of an inch.

This Annelide is rare, and is found buried in the sand. At Floroën in the Söndfjord it occurs in the Laminarian zone, so that when the reflux of the tide is very great, it may sometimes be obtained by digging. It was also taken at Manger, near Bergen, at a depth of 50-60 fathoms, and at Oxfjord, in Finmark, at 20-30 fathoms.

\section{Clymene Mülleri, Sars, n. s.}

Corpore segmentis 25-27, quorum 17-19 setigeris, 5 ante-analibus nudis; segmento anali margine cirris $15-23$ vel pluribus, quorum 2 ventrales cæteris duplo longiores sunt, ornato; lobo capitali declivi, ovato, plano, margine circumdato integro; segmentis 4 anterioribus setigeris modo aculeum in mamilla pedali ventrali gerentibus.

This species is usually found of about 4 inches in length and $\frac{1}{8}-\frac{1}{10}$ th of an inch in thickness, but imperfect specimens $\frac{1}{6}$ th of an inch thick have been met with, and these were probably of larger size. Its colour is yellowish or brownish-red, or flesh-colour; there is usually a darker ring across each segment at the point where the bristles are placed. It is the commonest species of the genus on the west coast of Norway, where it is found at a depth of $12-50$ fathoms. It lives in a cylindrical tube, open at both ends, composed of sand, fragments of shells, \&c., like that of Terebella. It approaches nearest to Clymene Ebiensis, Aud. and M.-Edw.

\section{Clymene quadrilobata, Sars, n. s.}

Corpore segmentis 26, quorum 19 setigeris, 5 ante-analibus nudis ; segmento anali margine cirris 35 , quorum uno ventrali cæteris longiore; lobo capitali declivi, ovato, plano, margine cristis duabus lateralibus cutaceis bilobatis circumdato; segmentis 3 anterioribus setigeris modo aculeum in mamilla pedali ventrali gerentibus.

Perfect specimens, of which only two have been met with, are about 5 inches long and $\frac{1}{10}$ th of an inch broad; the segments behind the middle of the body are of remarkable length. It is found rarely at Floroën and Manger at a depth of 20-40 fathoms.

Sabellides borealis, Sars, n. s.

Sabellides octocirrata, Sars, Mag. f. Naturv. 1850, p. 85.

Pollicaris, flava; cirris tentacularibus octo sulphureis ; tentaculis oralibus pinnatis; segmentis sectionis anterioris corporis 14, tribus anticis mamilla dorsali setis capillaribus instructa absque pinna ven- 
trali, cæterisque et pinna dorsali setis capillaribus et ventrali setis uncinatis; segmentis sectionis posterioris corporis 12 absque setis in pinna dorsali cirriformi, et setis uncinatis in pinna ventrali ; segmento anali cirris duobus.

This species, previously described erroneously by Sars as S. octocirrata, is an inch, or rather more, in length. Its colour is light yellow, and that of the tentacular cirri bright sulphur-yellow. It was found at Reine in Lofoten, and at Oxfjord in Finmark, at a depth of 50 fathoms on a muddy bottom.

\section{Sabellides sexcirrata, Sars, n. s.}

Pollicaris, fulva; cirris tentacularibus sex; segmentis sectionis anterioris corporis 17 , tribus anticis mamilla dorsali setis capillaribus instructa absque pinna ventrali, cæeterisque et pinna dorsali setis capillaribus et ventrali setis uncinatis; segmentis sectionis posterioris corporis 13 absque pinna dorsali et setis uncinatis in pinna ventrali; segmento anali cirris nullis.

A single specimen of this species was taken at Manger at the depth of 50-60 fathoms on a muddy bottom. In form and dimensions it resembles $S$. borealis.

\section{Sabellides cristata, Sars, n. s.}

Sesqui-bipollicaris, fulva; cirris tentacularibus octo; tentaculis oralibus filiformibus simplicibus (absque pinnis); segmentis sectionis anterioris corporis 18, tribus anticis fasciculo setarum capillarium dorsali absque mamilla pinna ventrali carente, cæterisque et pinna dorsali mamilla setis capillaribus et ventrali setis uncinatis ; segmentis sectionis posterioris corporis $50-53$ absque setis in pinna dorsali cirriformi minima et setis uncinatis in pinna ventrali; segmento anali cirris nullis.

The colour of the body of this Annelide is yellowish or miniumred, with the tentacular cirri light green; its length is $1 \frac{1}{2}-2$ inches, and that of the cirri $\frac{1}{3} \mathrm{rd}$ of an inch. It lives in a cylindrical tube of 5 or 6 inches in length, and $\frac{1}{10}-\frac{1}{8}$ th of an inch in thickness, resembling that of Sabella, and similarly formed of clay or mud. It is found pretty frequently in the vicinity of Manger, with the lower extremity of its tube attached to submarine objects, at a depth of 50-60 fathoms on a muddy bottom, and has also been met with, under the same circumstances, at Reine in Lofoten and at Havösund in Finmark.

\section{Sabellides octocirrata, Sars,}

the fourth Norwegian species described in 1835 by Sars, is only half an inch in length, of a fulvous colour, with the tentacular cirri greenish. It has only been met with hitherto in the neighbourhood of Bergen, near Glesvaer and Floroën, at a depth of 20-40 fathoms on a muddy bottom.-Fauna Littoralis Norvegia, part 2. pp. 9-24. 


\section{$2 \mathrm{BHL}$ Biodiversity Heritage Library}

Sars, M. 1857. "Descriptions of new Norwegian Annelides." The Annals and magazine of natural history; zoology, botany, and geology 20, 155-157. https://doi.org/10.1080/00222935709487895.

View This Item Online: https://www.biodiversitylibrary.org/item/19654

DOI: https://doi.org/10.1080/00222935709487895

Permalink: https://www.biodiversitylibrary.org/partpdf/3370

\section{Holding Institution}

Natural History Museum Library, London

\section{Sponsored by}

Natural History Museum Library, London

\section{Copyright \& Reuse}

Copyright Status: Public domain. The BHL considers that this work is no longer under copyright protection.

This document was created from content at the Biodiversity Heritage Library, the world's largest open access digital library for biodiversity literature and archives. Visit BHL at https://www.biodiversitylibrary.org. 